\title{
Reactions of $\mathrm{C}^{+}$with Ethane, Ethylene \\ and Acetylene
}

Ellen Lindemann, * R.W. Rozett, ${ }^{t}$ and W. S. Koski

Department of Chemistry

The Johns Hopkins University

Baltimore, Maryland 21218

The ion-molecule reactions of $C^{+}\left({ }^{2} p\right)$ with ethane, ethylene and acetylene in the gas phase have been investigated over a projectile energy ranging from a few eV to $100 \mathrm{eV}$. Ions with one, two, and three carbon atoms and varying number of hydrogen atoms were cosserved. The behavior. of the cross sections as a function of kinetic energy of the incident ion was used to infer reaction mechanism. The energetics of the processes were the most dominant parameters determining the courses of the reactions. 


\section{DISCLAIMER}

This report was prepared as an account of work sponsored by an agency of the United States Government. Neither the United States Government nor any agency Thereof, nor any of their employees, makes any warranty, express or implied, or assumes any legal liability or responsibility for the accuracy, completeness, or usefulness of any information, apparatus, product, or process disclosed, or represents that its use would not infringe privately owned rights. Reference herein to any specific commercial product, process, or service by trade name, trademark, manufacturer, or otherwise does not necessarily constitute or imply its endorsement, recommendation, or favoring by the United States Government or any agency thereof. The views and opinions of authors expressed herein do not necessarily state or reflect those of the United States Government or any agency thereof. 


\section{DISCLAIMER}

Portions of this document may be illegible in electronic image products. Images are produced from the best available original document. 


$$
\begin{gathered}
\text { Reactions of } \mathrm{C}^{+} \text {with Ethane, Ethylene } \\
\text { and Acetylene }
\end{gathered}
$$

Ellen Lindemann, ${ }^{*}$ R. W. Rozett, ${ }^{t}$ and W. S. Koski

Department of Chemistry

The Johns Hopkins University

Baltimore, Maryl and 21218

\section{Introduction}

A number of ion-molecule reactions involving $\mathrm{C}^{+}$and simple targets have been studied. ${ }^{1-7}$ In addition, the ion-molecule reactions of $\mathrm{C}^{+}$ with the methyl halides have been investigated by $P$. S. Wilson, et al. 8,9 Very few ion-molecule reactions of $\mathrm{C}^{+}$with more complex targets have been studied. Pohlet, et al ${ }^{10,11}$ have irradiated solid targets of benzene with ${ }^{14} \mathrm{C}^{+}$ ions and have observed the various products, and Wilson and Koskil have observed the gas phase reaction of $\mathrm{C}^{+}$with benzene and found ionic products containing from one to seven carbon atoms. In the references cited in which $\mathrm{C}^{+}$reactions were investigated in the gas phase, the cross sections were measured as a function of ion kinetic energy. These measurements enabled the investigators to infer the reaction mechanism. Hydride ion and hydrogen atom transfers were found to be common processes. $\mathrm{CH}_{3}{ }^{-}$, halide..ion, halogen atom, and $\mathrm{CH}_{3}$ pickup were found to be dominant modes of reaction wherever permitted by the energetics of the processes. In this report, the reactions of $c^{+}$ in the ground state are extended to target molecules of ethane, ethylene, and acetylene. Ionic products containing one, two, and three carbon atoms and varying number of hydrogen atoms are observed for energies ranging from a few eV to about $100 \mathrm{eV}$. The energetics of the processes 
appear to determine the course of the reactions.

\section{Experimental}

The tandem mass spectrometer used in this investigation has been described previously. ${ }^{13,14}$ It consists of two magnetic mass spectrometers in series. The first is a $180^{\circ}$ magnetic sector instrument with a $1-\mathrm{cm}$ radius of curvature. The secondary mass spectrometer, which analyzes the products extracted from the reaction chamber, is a $60^{\circ}$ magnetic sector instrument with an 8 in. radius of curvature. The pressure measurements in the reaction chamber were made with an MKS Baratron. Detection was made with a 17 stage electron multiplier. Single ion counting techniques were used. The $\mathrm{C}^{+}$ions were produced by electron bombardment of $\mathrm{CO}$. The conditions ${ }^{2}$ were such that the $\mathrm{C}^{+}$ions were in the ground state $\left({ }^{2} \mathrm{P}\right)$.

\section{Results and Discussion}

Endothermic ion-molecule reactions have cross sections which rise from some threshold value, go through a maximum, and then decline with kinetic energy of the bombarding ion. The cross sections of exothermic ionmolecule reactions, on the other hand, generally fall with increasing kinetic energy of the bombarding ions. This behavior has been used in this study to infer the exo or endothermicity of a particular reaction. This rationale, of course, cannot be used indiscriminately since there are a few exceptions to the above rules. 15

The reactions of $C^{+}\left({ }^{2} P\right)$ with ethane, ethylene, and acetylene in the gas phase give rise to ionic products containing one, two, and three carbon atoms. Fig. 1 gives the variation of the cross section for the 
production of two carbon ions with the $\mathrm{C}^{+}$ion laboratory kinetic energy for the reaction of $\mathrm{C}^{+}$with ethane. The product corresponding to the parent ion, $\mathrm{C}_{2} \mathrm{H}_{6}^{+}$, clearly arises from a charge transfer process. This reaction gives a typical cross section behavior of an endothermic reaction $(-0.238 \mathrm{eV}) .^{16}$ In the low energy region, the $\mathrm{C}_{2} \mathrm{H}_{5}{ }^{+}$ion is the most abundant ion the 2 carbon ion series arising from ethane. The variation of the cross section with $\mathrm{C}^{+}$. ion energy is typical of an exothermic ion-molecule reaction. The most likely reaction leading to this product is hydride ion transfer which is exothermic by $2.14 \mathrm{eV}$

$$
\mathrm{C}^{+}+\mathrm{C}_{2} \mathrm{H}_{6} \rightarrow \mathrm{C}_{2} \mathrm{H}_{5}^{+}+\mathrm{CH} \quad \Delta \mathrm{H}=2.14 \mathrm{eV}
$$

The cross sections vs energy curves for the ions $\mathrm{C}_{2} \mathrm{H}_{4}^{+}, \mathrm{C}_{2} \mathrm{H}_{3}^{+}$, and $\mathrm{C}_{2} \mathrm{H}_{2}{ }^{+}$behave in a similar manner, i.e. they fall at low energies and then flatten off to a plateau. They are exothermic reactions, and it is tempting to assign them a related mechanism namely $\mathrm{H}_{2}{ }^{-}$transfer followed by dissociation. An argument against this interpretation is the calculated endothermicity of the reaction producing $\mathrm{C}_{2} \mathrm{H}_{3}^{+}$

$$
\begin{aligned}
\mathrm{C}^{+}+\mathrm{C}_{2} \mathrm{H}_{6}+\mathrm{CH}_{2}+\mathrm{C}_{2} \mathrm{H}_{4}^{+} & \Delta \mathrm{H} & =2.81 \mathrm{eV} \\
+\mathrm{CH}_{2}+\mathrm{H}+\mathrm{C}_{2} \mathrm{H}_{3}^{+} & & =-0.15 \\
\mathrm{CH}_{2}+\mathrm{H}_{2}+\mathrm{C}_{2} \mathrm{H}_{2}^{+} & & =0.03
\end{aligned}
$$

An alternate mechanism for the three reactions is $\mathrm{CH}_{2}, \mathrm{CH}_{3}$ and $\mathrm{CH}_{4}$ pickup.

$$
\mathrm{C}^{+}+\mathrm{C}_{2} \mathrm{H}_{6} \rightarrow \mathrm{C}_{2} \mathrm{H}_{4}^{+}+\mathrm{CH}_{2} \quad \Delta \mathrm{H}=2.78
$$




$$
\begin{aligned}
& \rightarrow \mathrm{C}_{2} \mathrm{H}_{3}^{+}+\mathrm{CH}_{3} \quad=4.71 \\
& \rightarrow \mathrm{C}_{2} \mathrm{H}_{2}^{+}+\mathrm{CH}_{4} \quad=4.84
\end{aligned}
$$

A dissociative hydride ion transfer to form $\mathrm{CH}$ with the appropriate ions is ruled out since all of the reactions are endothermic. Dissociative charge transfer for the second and third reactions in this series can also be ruled out by the endothermicity of such processes (Table 1). However, the possibility of forming $\mathrm{C}_{2} \mathrm{H}_{4}{ }^{+}$by dissociative charge transfer cannot be ruled out since such a process would be exothermic by $0.58 \mathrm{eV}$ as calculated from existing thermodynamic data.

The production of $\mathrm{C}_{2} \mathrm{H}^{+}$in this series is typical of an endothermic reaction. Its cross section is small, and the yield goes through a broad maximum and is unobservable above $40 \mathrm{eV}$.

The three carbon and one carbon ion yields from the reaction of $\mathrm{C}^{+}$with ethane are given in Fig. 2. The ions $\mathrm{C}_{3} \mathrm{H}_{6}^{+}, \mathrm{C}_{3} \mathrm{H}_{5}^{+}$, and $\mathrm{C}_{3} \mathrm{H}_{4}^{+}$ do not appear in detectable amounts possibly because of the high exothermicities (8.0, 6.2 and $5.7 \mathrm{eV}$ respectively) of the processes which lead to their production. Such large amounts of internal energy shorten the lifetimes of these ions to such an extent that they are much shorter than the transit times in our instrument and, hence, are not detected. $\mathrm{C}_{3} \mathrm{H}_{3}^{+}$and $\mathrm{C}_{3} \mathrm{H}_{2}^{+}$, the processes for which are exothermic by 4.5 and $1.98 \mathrm{eV}$ respectively, decline monotonically whereas $\mathrm{C}_{3} \mathrm{H}^{+}$, which is endothermic by $1.8 \mathrm{eV}$, rises from a threshold and then falls. The cross sections for these three-carbon ions fall below a measurable value when the projectile $\left(\mathrm{C}^{+}\right)$ion energy approaches $20 \mathrm{eV}$ in the 1aboratory system. 
The $\mathrm{C}_{3}{ }^{+}$ion was not observed probably because of the high endothermicity $(3.0 \mathrm{eV})$ of the process by which it can be produced. The general behavior of the cross sections of these three-carbon ions suggests that complex formation is the mechanism by which they are formed, and the high excitation energy results in successive decomposition of the various ions to give rise to the observed species.

This conclusion is experimentally supported by our measurements since in our instrument we can readily determine if the product ion has a significant amount of kinetic energy in the beam direction (as it would have for a direct mechanism) by its behavior with repeller voltage. 13,14 This also is compatible with the indication that ion-molecule systems which have a larger number of degrees of freedom are more likely to form persistent complexes as intermediates than ones that have a few degrees of freedom. 17

In the low energy region, $\mathrm{CH}_{3}{ }^{+}$is the most abundant single carbon ion formed in these reactions with $\mathrm{C}_{2} \mathrm{H}_{6}$. It is produced by an exothermic process, hence, cannot result from dissociative charge transfer $(-2.32 \mathrm{eV})$, nor hydride $\left(\mathrm{H}^{-}\right)$transfer $(-3.67)$ or $\mathrm{H}_{2}^{-}$transfer $(-3.67 \mathrm{eV})$; but it can arise from complex formation with successive dissociation or it can arise from carbanion $\left(\mathrm{CH}_{3}{ }^{-}\right)$, abstraction which is exothermic by $3.7 \mathrm{eV}$. The $\mathrm{CH}_{2}^{+}$ ion yield is very similar to that of $\mathrm{CH}_{3}^{+}$, both of which become undectable when the $\mathrm{C}^{+}$ion energy reaches $40 \mathrm{eV}$. The slope of the curve indicates it is an exothermic process. Again dissociative charge transfer, hydride ion transfer, or $\mathrm{H}_{2}{ }^{-}$transfer are ruled out since they are endothermic. However, it is to be noted $\mathrm{C}^{+}+\mathrm{C}_{2} \mathrm{H}_{6} \rightarrow \mathrm{CH}_{2}{ }^{+}+\mathrm{C}_{2} \mathrm{H}_{4}$ is exothermic $(2.83 \mathrm{eV})$. so it is a possible source of the $\mathrm{CH}_{2}{ }^{+}$ion. The similarity of the $\mathrm{CH}_{2}{ }^{+}$cross section curve to $\mathrm{CH}_{3}{ }^{+}$suggests that $\mathrm{CH}_{2}{ }^{+}$formation results from dissociative complex formation, and it is the high energy successor to the three carbon products. 
The cross section for production of $\mathrm{CH}^{+}$has a threshold, and it is expected to be endothermic $(0.6 \mathrm{eV})$. Initially, it is lower than ${ }^{\circ} \mathrm{CH}_{2}{ }^{+}$; but as the kinetic energy of the $\mathrm{C}^{+}$ion increases, ${ }^{\circ} \mathrm{CH}^{+}$exceeds $\sigma_{\mathrm{CH}_{2}}{ }^{+}$, and it goes through a broad maximum. The only process that appears to be compatible with this behavior is $\mathrm{H}$ atom pickup, and the apparent threshold is not incompatible with this conclusion. Other processes such as charge transfer, hydride ion pickup or $\mathrm{H}_{2}^{-}$pickup followed by dissociation to $\mathrm{CH}^{+}$ are ruled out since they would be much more endothermic and, consequentiy, would exhibit a much higher threshold than the observed one.

Fig. 3 gives the cross sections for the processes producing the two and one carbon ionic products from the reaction $\mathrm{C}^{+}+\mathrm{C}_{2} \mathrm{H}_{4}$. It will be noted that the cross section curve for $\mathrm{C}_{2} \mathrm{H}_{4}^{+}$has been reduced to one fourth of the observed value in order to conveniently include it in the figure. The actual yield of this ion is much greater than any other product in this group of reactions. It arises from an exothermic $(0.83 \mathrm{eV})$ charge transfer process. The $\mathrm{C}_{2} \mathrm{H}_{3}^{+}$ion arises from hydride ion transfer which process is exothermic by $1.53 \mathrm{eV}$, consistent with experimental observation. Other processes are ruled out because of their endothermicity (see Table 1).

The process producing the $\mathrm{C}_{2} \mathrm{H}^{+}$ion is observed to be exothermic; and on the basis of the thermodynamic values, the only process compatible with this is $\mathrm{H}_{2}{ }^{-}$ transfer. The $\mathrm{C}_{2} \mathrm{H}^{+}$ion appears to be formed by an exothermic process, and the only candidate reaction for this product is $\mathrm{C}^{+}+\mathrm{C}_{2} \mathrm{H}_{4} \rightarrow \mathrm{C}_{2} \mathrm{H}^{+}+\mathrm{CH}_{3}$ $(0.5 \mathrm{eV})$.

of the single carbon ions in this reaction, $\mathrm{CH}_{2}^{+}$is the only one observed. The reaction appears to be exothermic, and $\mathrm{H}_{2}$ transfer is a likely process since it is expected to be exothermic by $2.4 \mathrm{eV}$ (see Table 1). 
Fig. 4 summarizes the results on the three carbon ion fragments from this reaction. $\mathrm{C}_{3} \mathrm{H}_{4}{ }^{+}$is not observed presumably because of the high exothermicity $(7.1 \mathrm{eV})$ which leads to a short lifetime and rapid dissociation to ions with fewer hydrogen. $\mathrm{C}_{3} \mathrm{H}_{3}{ }^{+}$which is formed through an exothermic process with a high $\Delta H=5.9 \mathrm{eV}$ is observed but with a very small cross section.

The $\mathrm{C}_{3}^{+}$ion results from an endothermic process $(\Delta \mathrm{H}=-0.4 \mathrm{eV})$. The $\mathrm{C}_{3} \mathrm{H}^{+}$ion appears, from our experimental results, to arise from an exothermic process. We cannot make a significant comparison with existing thermodynamic data on this ion because of the lack of reliable measurements on the quantity. All of these three carbon ions are probably produced by complex formation and subsequent decomposition. This is supported by the general behavior of these ions with repeller voltage.

The cross sections for the ionic products from the reaction of $\mathrm{C}^{+}$with acetylene are given in Fig. 5. Only the three carbon atom ionic products are expected to be exothermic in this system. The ion $\mathrm{C}_{3} \mathrm{H}_{2}^{+}$was not observed presumably because of high exothermicity $(5.25 \mathrm{eV})$ of the reaction giving rise to the ion. The products $\mathrm{C}_{3} \mathrm{H}^{+}$and $\mathrm{C}_{3}{ }^{+}$are both expected to arise from exothermic reactions, and their cross section curves seem to support this. A reasonable mechanism for the production of the three carbon atom ions is complex formation followed by dissociation.

All of the two carbon atom ions in this reaction are expected to arise from endothermic processes, and this seems to be borne out by the experimental results. $\mathrm{C}_{2} \mathrm{H}_{2}^{+}$. arises from an endothermic charge transfer process and its cross section curve rises from a threshold value and then flattens out in the higher energy region. The $\mathrm{C}_{2} \mathrm{H}^{+}$ion probably 
results from hydride ion transfer judging from analogy between other hydrocarbon reactions with $\mathrm{C}^{+}$; however, the experimental results are also compatible with the production of this ion from charge transfer and subsequent dissociation of $\mathrm{C}_{2} \mathrm{H}_{2}{ }^{+}$. Similar comments could be applied to $\mathrm{C}_{2}{ }^{+}$which can arise from $\mathrm{H}_{2}^{-}$transfer or from charge transfer and dissociation of $\mathrm{C}_{2} \mathrm{H}_{2}^{+}$. Either of these mechanisms would be compatible with appearance of a threshold and the flatness of the cross section curves in the higher energy region. One might be tempted to use similar arguments as far as the production of $\mathrm{CH}^{+}$is concerned, i.e. it results from charge transfer followed by dissociation. However, one would expect the cross section curve to be flat in the higher energy regions much like the $\mathrm{C}_{2} \mathrm{H}^{+}$ion curve. The fact that the $\mathrm{CH}^{+}$cross section curve rises from a threshold goes through a broad maximum and has a critical energy beyond which its yield disappears suggests that it arises by an $\mathrm{H}$ atom pickup mechanism. If one had accurate thermodynamic information, this suggestion could be tested from the observed threshold value and the critical energy.

In Figures $1-5$, the symbols represent data points and each point indicated is an average of several observations. In general, our reproducibility is $5 \%$. The absolute accuracy of the cross sections is difficult to estimate because of uncertainties in ion collection efficiencies. In a number of instances, we have had the opportunity to compare our cross sections with those obtained in other laboratories using instruments whose designs differed considerably from ours. The agretment between the cross sections in these comparisons was within $25 \%$.

This work was done under the auspices of the U. S. Atomic Energy Commission. 


\section{References}

Deceased

f Present address: Department of Chemistry, Fordham University, Bronx, New York

1. R. C. C. Lao, R. W. Rozett, and W. S. Koski, J. Chem. Phys., 49, 4202 (1968).

2. P.. S. Wilson, R. W. Rozett, and W. S. Koski, J. Chem. Phys., 52, $5321(1970)$.

3. C. R. Iden, R. Liardon, and W. S. Koski, J. Chem. Phys., 54, 5757 (1971).

4. J. J. Leventhal, J. Chem. Phys., 55, 4654 (1971).

5. F. C. Fehsenfeld, A. L. Schmeltekopf, and E. E. Ferguson, J. Chem. Phys. $\underline{45}, 23(1966)$.

6. J. L. Franklin and M. S. B. Munson, Tenth Combustion Symposium, Combustion Institute, Pittsburgh, Pa. (1965).

7. W. B. Maier II, J. Chem. Phys., 46, 4991 (1967).

8. P. S. Wilson, R. W. Rozett, and W. S. Koski, J. Chem. Phys., 53, $1276(1970)$.

9. P. S. Wilson, R.W. Rozett, and W. S. Koski, J. Chem. Phys., 53, $3494(1970)$.

10. H. M. Pohlet, Tz-Hong Lin, W. Erwin, and R. M. Lemmon, J. Am. Chem. Soc., 91, 5421. (1969).

11. H. M. Pohtet, Tz-Hong Lin, and R. M. Lemmon, J. Am. Chem. Soc., 9l, 5425 (1969).

12. P. S. Wilson and W. S. Koski, unpublished results. 
13. E. R. Weiner, G. R. Hertel, and W. S. Koski, J. Am. Chem. Soc., 86, 788 (1964).

14. R. W. Rozett and W. S. Koski, J. Chem. Phys., 49, 2691 (1968).

15. Joyce J. Kaufman and W. S. Koski, J. Chem. Phys., 50, 1942 (1969).

16. Ellen Lindemann, Louis C. Frees, R. W. Rozett and W. S. Koski, J. Chem. Phys., 56, 1003 (1972).

17. R. Wolfgang, Accounts of Chemical Research, 2, 248 (1969).

18. J. L. Franklin, J. G. Dillard, H. M. Rosenstock, J. T. Herron, K. Draxl, and F. H. Field, Natl. Std. Ref. Data Ser., Natl. Bur. Std. (U. S.), 26, (1969). 


\section{Table 1}

$$
\begin{gathered}
\text { Heats }{ }^{(a)} \text { of reaction }(e V) \text { for the } \\
\text { reactions of } c^{+}\left({ }^{2} p\right)+C_{2} H_{n}
\end{gathered}
$$

$$
\text { Reaction Products of } \mathrm{C}^{+}+\mathrm{C}_{2} \mathrm{H}_{6} \text {. }
$$

$$
\begin{array}{lc}
\mathrm{C}^{+} \mathrm{C}_{2} \mathrm{H}_{6}^{+} & -0.238 \\
\mathrm{CH}+\mathrm{C}_{2} \mathrm{H}_{5}^{+} & 2.14 \\
\mathrm{CH}_{2}+\mathrm{C}_{2} \mathrm{H}_{4}^{+} & 2.78 \\
\mathrm{CH}_{2}+\mathrm{H}+\mathrm{C}_{2} \mathrm{H}_{3}^{+} & -0.15 \\
\mathrm{C}_{2} \mathrm{H}_{2}^{+}+\mathrm{H}_{2}+\mathrm{CH}_{2} & 0.03 \\
\mathrm{C}_{2} \mathrm{H}_{4}^{+}+\mathrm{H}_{2}+\mathrm{C} & 0.58 \\
\mathrm{C}_{3} \mathrm{H}_{6}^{+} & 8.01 \\
\mathrm{C}_{3} \mathrm{H}_{5}^{+}+\mathrm{H}^{+} & 6.19 \\
\mathrm{C}_{3} \mathrm{H}_{4}^{+}+\mathrm{H}_{2} & 5.67 \\
\mathrm{C}_{3} \mathrm{H}_{3}^{+}+\mathrm{H}_{2}+\mathrm{H} & 4.54 \\
\mathrm{C}_{3} \mathrm{H}_{2}^{+}+2 \mathrm{H}_{2} & 1.98 \\
\mathrm{C}_{3} \mathrm{H}^{+}+2 \mathrm{H}_{2}+\mathrm{H} & (-1.80) \\
\mathrm{CH}_{3}{ }^{+}+\mathrm{C}_{2} \mathrm{H}_{3} & 3.72 \\
\mathrm{CH}_{2}^{+}+\mathrm{C}_{2} \mathrm{H}_{4} & 2.83 \\
\mathrm{CH}^{+}+\mathrm{C}_{2} \mathrm{H}_{5} & -0.57
\end{array}
$$




\section{a Heats of reaction (eV) for the reactions of $C^{+}\left({ }^{2} P\right)+C_{2} H_{n}$ (continued)}

$$
\text { Reaction Products of } \mathrm{C}^{+}+\mathrm{C}_{2} \mathrm{H}_{4}
$$
$\mathrm{C}_{2} \mathrm{H}_{4}^{+}+\mathrm{C}$
0.83
$\mathrm{C}_{2} \mathrm{H}_{3}^{+}+\mathrm{CH}$
1.53
$\mathrm{C}_{2} \mathrm{H}_{2}^{+}+\mathrm{CH}_{2}$
1.42
$\mathrm{C}_{2} \mathrm{H}^{+}+\mathrm{CH}_{3}$
0.49
$\mathrm{CH}_{2}^{+}+\mathrm{C}_{2} \mathrm{H}_{2}$
2.44
$\mathrm{C}_{3} \mathrm{H}_{4}^{+}$
7.09
$\mathrm{C}_{3} \mathrm{H}_{3}^{+}+\mathrm{H}$
5.91
$\mathrm{C}_{3} \mathrm{H}^{+}+\mathrm{H}+\mathrm{H}_{2}$
$(-0.37)^{\mathrm{b}}$
$\mathrm{C}_{3}^{+}+2 \mathrm{H}_{2}$
$-7.58$

- Reaction Products of $\mathrm{C}^{+}+\mathrm{C}_{2} \mathrm{H}_{2}$

$\mathrm{C}_{3} \mathrm{H}_{2}^{+}$

$\mathrm{C}_{3} \mathrm{H}^{+}+\mathrm{H}$

$(1.44)^{b}$

$\mathrm{C}_{3}^{+}+\mathrm{H}_{2}$

0.23

$\mathrm{C}_{2} \mathrm{H}_{2}^{+}+\mathrm{C}$

$-0.13$

$\mathrm{C}_{2} \mathrm{H}^{+}+\mathrm{CH}$

$-2.44$

$\mathrm{CH}^{+}+\mathrm{C}_{2} \mathrm{H}$

$-1.12$

(a) All heats of reaction were calculated using the compilation of Franklin, et. al. 18

(b) Indicates considerable uncertainty in value of the heat of reaction 


\section{Figure Captions}

Figure 1 Cross sections vs $\mathrm{C}^{+}$kinetic energy for reaction of $\mathrm{C}^{+}+\mathrm{C}_{2} \mathrm{H}_{6}$ to give $\square \mathrm{C}_{2} \mathrm{H}_{6}^{+}, \Delta \mathrm{C}_{2} \mathrm{H}_{5}^{+}, \mathrm{OC}_{2} \mathrm{H}_{4}^{+}, \mathrm{C}_{2} \mathrm{H}_{3}^{+}, \diamond \mathrm{C}_{2} \mathrm{H}_{2}^{+}$, and $\mathrm{C}_{2} \mathrm{H}^{+}$

Figure 2 Cross sections vs $\mathrm{C}^{+}$kinetic energy for reaction of $\mathrm{C}^{+}+\mathrm{C}_{2} \mathrm{H}_{6}$ to give $\mathrm{C}_{3} \mathrm{H}_{3}^{+}, \triangle \mathrm{C}_{3} \mathrm{H}_{2}^{+}, \mathrm{C}_{3} \mathrm{H}^{+}, \square \mathrm{CH}_{3}^{+}, \nabla \mathrm{CH}_{2}^{+}$, and $0 \mathrm{CH}^{+}$

Figure 3 Cross sections for the reaction of $\mathrm{C}^{+}$with $\mathrm{C}_{2} \mathrm{H}_{4}$ to give $\Delta \mathrm{C}_{2} \mathrm{H}_{4}^{+}, 0 \mathrm{C}_{2} \mathrm{H}_{3}^{+}, \mathrm{C}_{2} \mathrm{H}_{2}^{+}, \Delta \mathrm{C}_{2} \mathrm{H}^{+}$, and $\mathrm{CH}_{2}^{+}$. The $\mathrm{C}_{2} \mathrm{H}_{4}{ }^{+}$cross section is given as one quarter of its observed value.

Figure 4 Cross sections for the reaction of $\mathrm{C}^{+}$with $\mathrm{C}_{2} \mathrm{H}_{4}$ to give - $\mathrm{C}_{3} \mathrm{H}_{3}^{+}, \mathrm{O} \mathrm{C}_{3} \mathrm{H}_{2}^{+}, O \mathrm{C}_{3} \mathrm{H}^{+}$, and $\mathrm{C}_{3}^{+}$.

Figure 5 Cross sections for the reaction of $\mathrm{C}^{+}$with $\mathrm{C}_{2} \mathrm{H}_{2}$ to produce $\diamond \mathrm{C}_{3} \mathrm{H}^{+}, \nabla \mathrm{C}_{3}^{+}, \mathrm{C}_{2} \mathrm{H}_{2}^{+}, \mathrm{OC}_{2} \mathrm{H}^{+}, \square \mathrm{C}_{2}^{+}$, and $\mathrm{CH}^{+}$. 


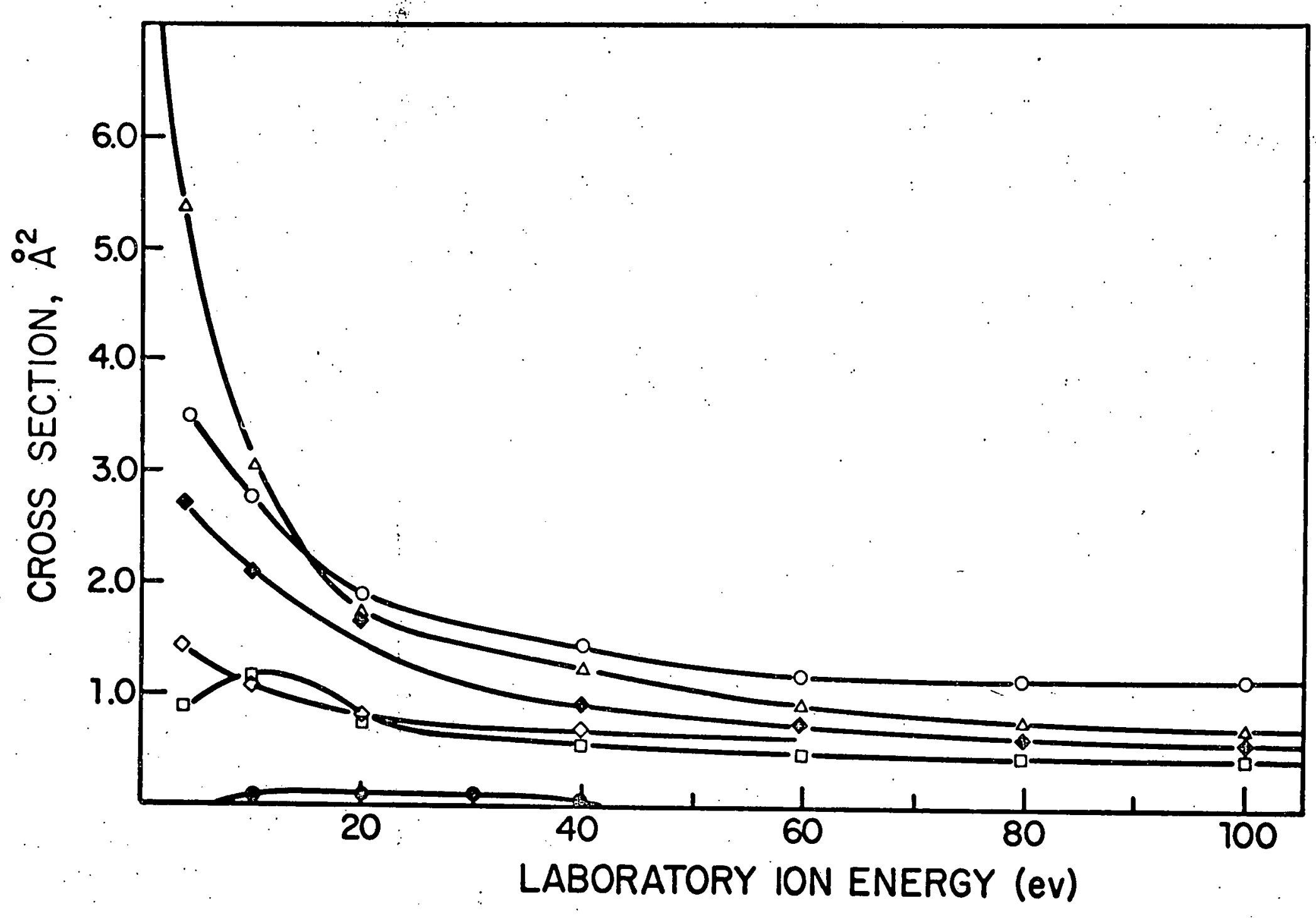




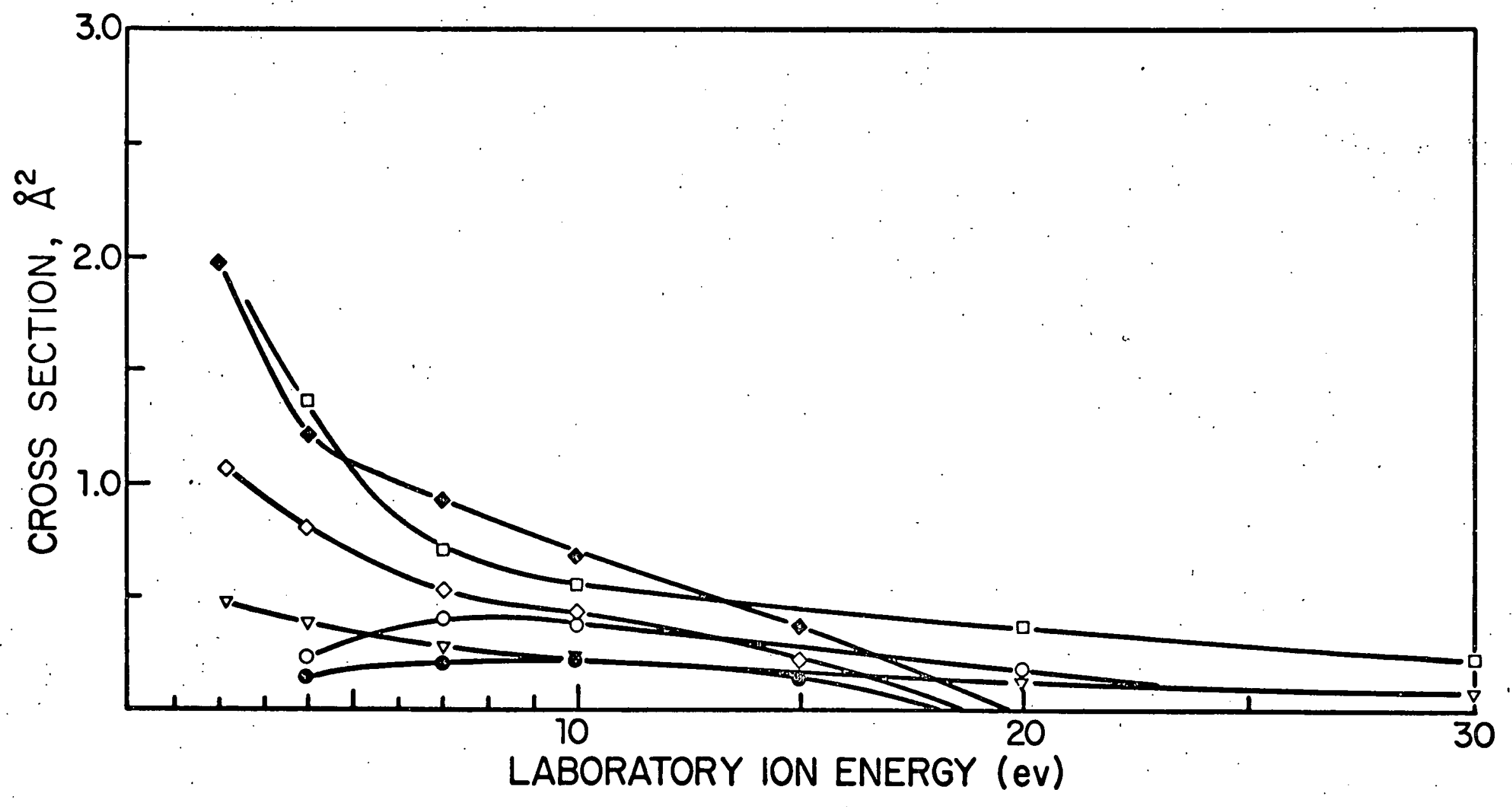

ir 


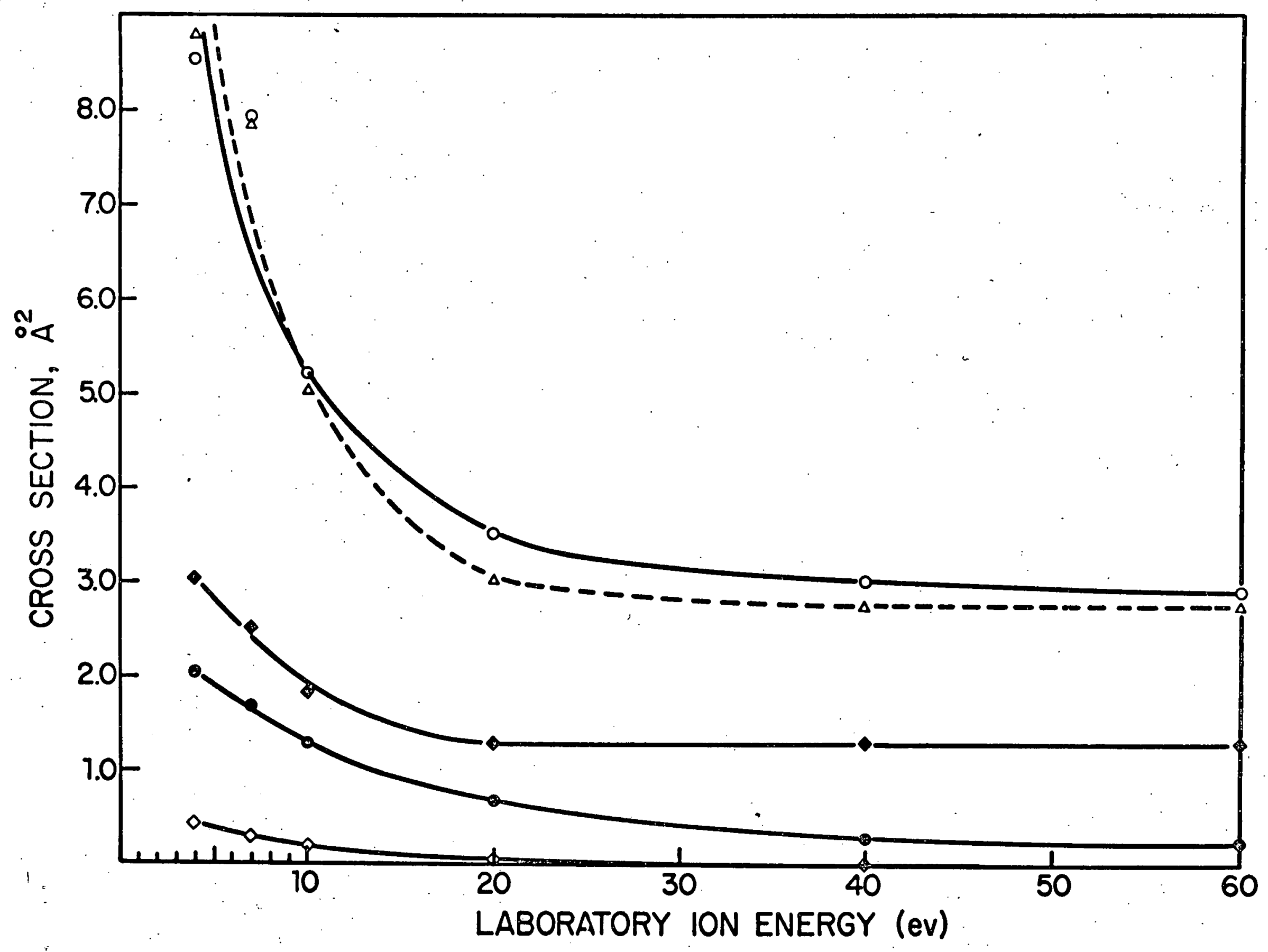

$\dot{m}$ 


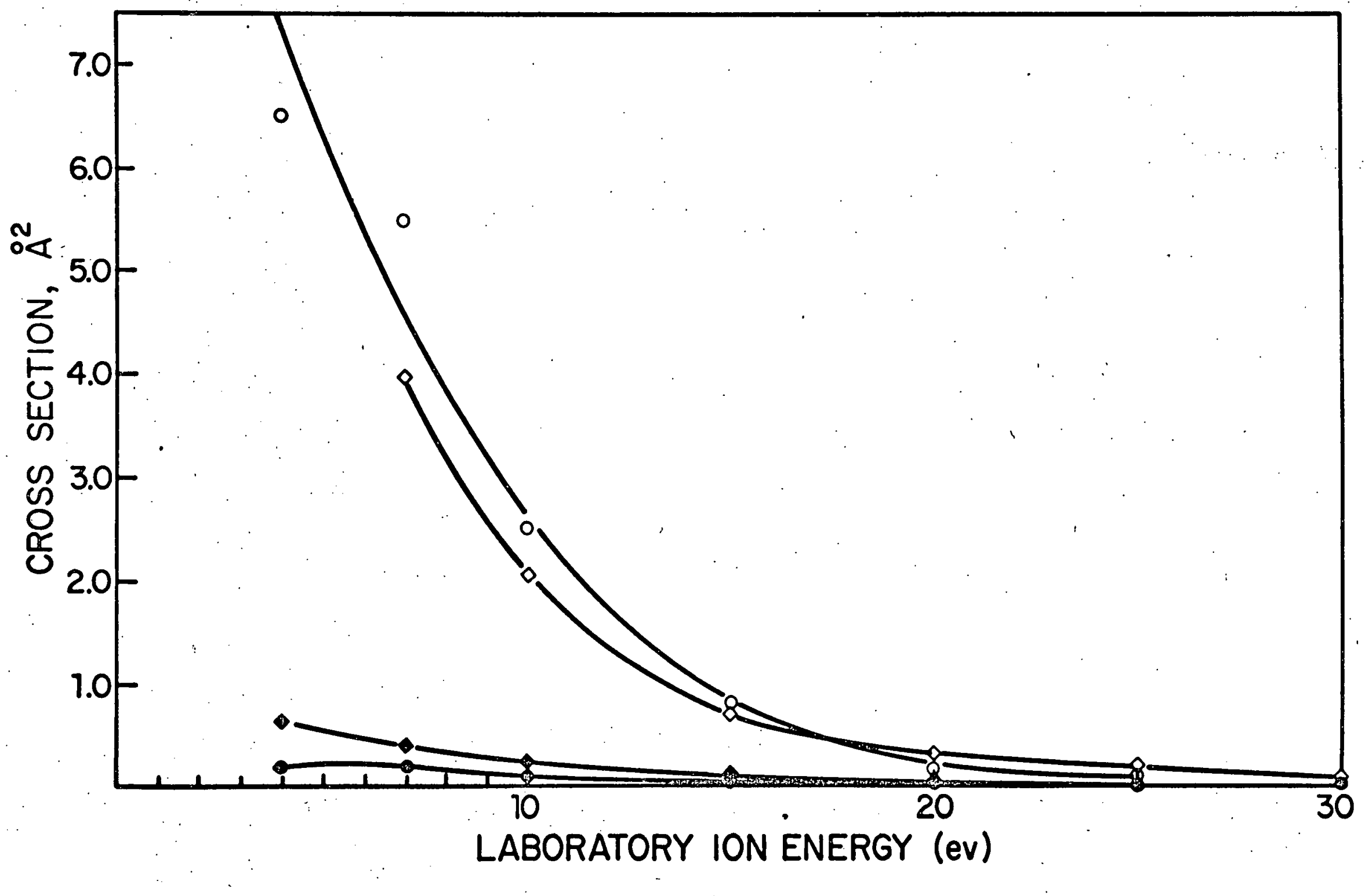




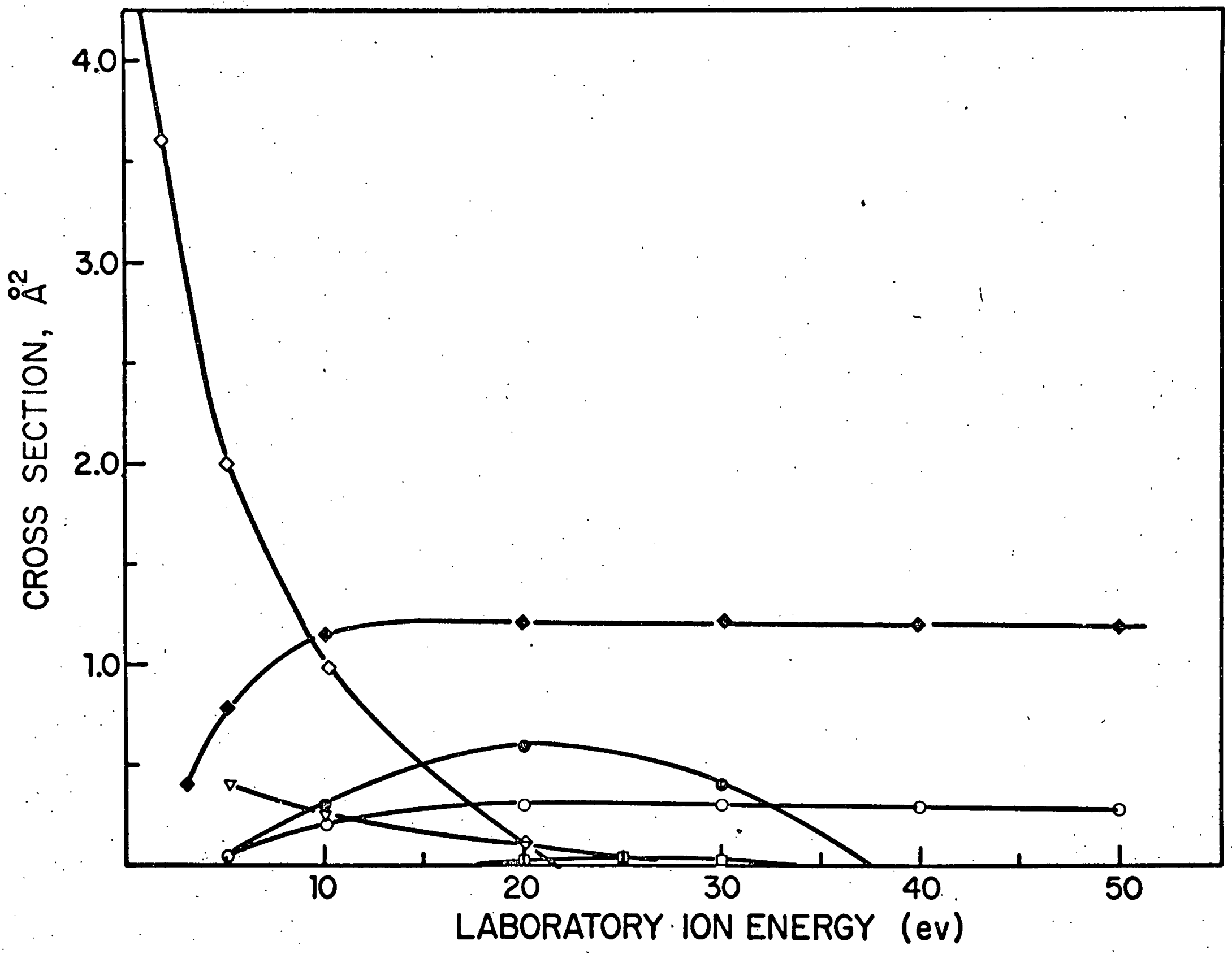

$\dot{0}$ 